\title{
Physico Chemical Characterization of Tannery Effluent and Its Impact on the Nearby River
}

\author{
Haile Reda Amanial \\ Department of Chemistry, College of Natural Sciences, Arba Minch University, Arba Minch, Ethiopia \\ Email: manuyehaile@gmail.com
}

Received 18 February 2016; accepted 4 March 2016; published 8 March 2016

Copyright (C) 2016 by author and OALib.

This work is licensed under the Creative Commons Attribution International License (CC BY).

http://creativecommons.org/licenses/by/4.0/

(c) $\underset{\mathrm{EY}}{\mathrm{B}}$ Open Access

\section{Abstract}

A study was conducted to characterize Modjo tannery effluent (wastewater) and determine its impact on the Modjo River using some physicochemical parameters. Accordingly, three tannery wastewater samples along wastewater channel at different distances have been taken and three river water samples (one upstream and two downstream) were collected along the river to determine its impact on the river. The samples have been analyzed for temperature, $\mathrm{pH}$, electrical conductivity (EC), total dissolved solids (TDS), total suspended solid (TSS), chloride( $\mathrm{Cl}^{-}$), biological oxygen demand (BOD5), chemical oxygen demand (COD), total ammonia (as $N$ ), total nitrogen, total phosphorus and sulphide. The result of tannery wastewater showed that the values of temperature, $\mathrm{pH}, \mathrm{EC}, \mathrm{TDS}, \mathrm{TSS}, \mathrm{Cl}^{-}$, BOD5, COD, total ammonia, total nitrogen, total phosphorus and sulphide along the wastewater channel ranged from $26.97^{\circ} \mathrm{C}$ to $24.93^{\circ} \mathrm{C}, 9.33$ to $8.33,15,670.00$ to $14,496.67 \mathrm{mg} \cdot \mathrm{L}^{-1}, 9370.00$ to $8723.33 \mathrm{mg} \cdot \mathrm{L}^{-1}, 4979.33$ to $2647.67 \mathrm{mg} \cdot \mathrm{L}^{-1}, 6111.67$ to 5555.78 $\mathrm{mg} \cdot \mathrm{L}^{-1}, 960.34$ to $842.00 \mathrm{mg} \cdot \mathrm{L}^{-1}, 2011.00$ to $1950.75 \mathrm{mg} \cdot \mathrm{L}^{-1}, 520.44$ to $401.23 \mathrm{mg} \cdot \mathrm{L}^{-1}, 720.46$ to $665.43 \mathrm{mg} \cdot \mathrm{L}^{-1}, 30.12$ to $19.55 \mathrm{mg} \cdot \mathrm{L}^{-1}, 35.56$ to $21.05 \mathrm{mg} \cdot \mathrm{L}^{-1}$ respectively. And most of the effluent characteristics except $\mathrm{pH}$ and temperature were beyond the provisional discharge limit of tannery effluent to water body set by the Ethiopian Environmental Protection Authority (EEPA) and Federal Environmental Protection Agency (FEPA). Analysis of variance (ANOVA) also showed that variation among sampling points was statistically significant $(p<0.5)$. Similarly the levels of all these physicochemical parameters in the downstream site of the river were higher as compared to the values obtained from the upstream site (control). This indicated that the downstream site of the river was polluted as the result of the direct discharge of the tannery effluent to it.

\section{Keywords}

Modjo Tannery, Modjo River, Wastewater, Physicochemical Parameters, Water Pollution

Subject Areas: Analytical Chemistry, Environmental Chemistry 


\section{Introduction}

Tannery industry is making pronounced impacts on socioeconomics through employment and earning, yet the industry has gained a negative image in the society owing to the pollution it generates. Leather processing involves a series of unit operations including pre-tanning, tanning, and post-tanning/finishing [1]. At each stage, various chemicals are used, and varieties of materials are expelled in addition to 35 - $40 \mathrm{~L}$ of water used per kilogram of hide processed [2]. Moreover, excessive amounts of chemicals are used in treatment drums, and it has been reported that $50 \%$ of the chemicals used in these processes become wastewater or sludge [3].

Therefore, tanning industry is considered as an activity with elevated potential for environmental pollution [4]. Generally, leather tanneries produce three different types of wastes such as solid, liquid (waste water) and gas wastes and out of this wastewater is the most challenge to the environment. The tanning process is almost wholly a wet process that consumes high amount of water that is estimated to be $34-56 \mathrm{~m}^{3}$ of water per ton of hides or skin processed where $85 \%$ of the total water consumed is discharged as a wastewater [5] [6]. Process water consumption, and consequently wastewater effluent discharges, varies greatly between tanneries, based on the processes involved, raw materials, and products [7] [8]. Generally, water consumption is the greatest in the pre-tanning areas, but significant amounts of water are also consumed in the post tanning processes [9].

Reference [10] reported that Tannery wastewater was highly polluted in terms of suspended solids, nitrogen, conductivity, sulphate, sulphide, chloride, biological oxygen demand, chemical oxygen demand, and chromium. Reference [4] also stated that effluents from tanning units were discharged indiscriminately into natural water bodies or open lands, resulting in contamination of the surface and ground waters as well as the soil flora and fauna. The high salinity and TDS of the effluent may result in physiologically stressful conditions for some species of aquatic organisms due to alterations in osmotic conditions. The high BOD5 content of the effluent may also affect the survival of gill breathing animals of the receiving water body and high COD value indicates toxic state of the wastewater along with presence of biologically resistant organic substances. The high level of ammonia- $\mathrm{N}$ is toxic to aquatic organism and nitrogen may cause eutrophic condition. Some reports also show that changes in the ionic composition of water can also exclude some species while promoting population growth of others [11]. The pollutants are poisonous to man and aquatic life resulting in food contamination.

Currently there are more than 20 tanning industries operating in Ethiopia and only 10\% of the existing tanning industries treat their wastewater to any degree, while the majority (90\%) discharges their wastewater into nearby water bodies, streams and open land without any kind of treatment [12]. This makes industrial and chemical pollution become the third major problem in the country and one of the great environmental concerns [13]. Similarly, Modjo tannery is one of the 14 tanneries located along Modjo in which its untreated wastewater discharge directly into the Modjo River. The downstream part of the river is used for domestic activities including drinking, irrigation and recreation (swimming and bathing). The use of the river in this way may lead to bioaccumulation of toxic pollutants which is hazardous to human beings as well as livestock. In view of the negative impact of this effluent on the environment, the present study aimed at determining the levels of physicochemical pollutants in effluent samples from the tannery and assessing its impact on the nearby Modjo River.

\section{Materials and Methods}

\subsection{General Description of Sampling Site}

Modjo is a town in East Showa Oromiya region Ethiopia and has a latitude and longitude of $8^{\circ} 35^{\prime} \mathrm{N}$ and $39^{\circ} 07^{\prime}$ E with an elevation between 1788 and 1825 meters above sea level respectively. Modjo tanning industry, which is found in Modjo town is located $80 \mathrm{kms}$ South of Addis Ababa and is a medium-sized leather industry in Ethiopia with installed capacity of processing 844,000 and 1,656,000 sheep and goatskins, respectively, per annum [14]. The plant is sited near the Modjo River and channels its effluents directly to the river course. The volume of wastewater discharged into the Modjo River varies between 3500 - 5500 cubic meters per day (Figure 1).

\subsection{Tannery Effluent (Wastewater) and River Water Sampling}

Tannery effluent (wastewater) samples were collected along the wastewater channel (drain) at different distance and designated as E1, E2 and E3 and three sampling site (one upstream and two downstream sites) were established along the river length to assess the impact of the effluent on the river and designated as Wup, W1 and W2 


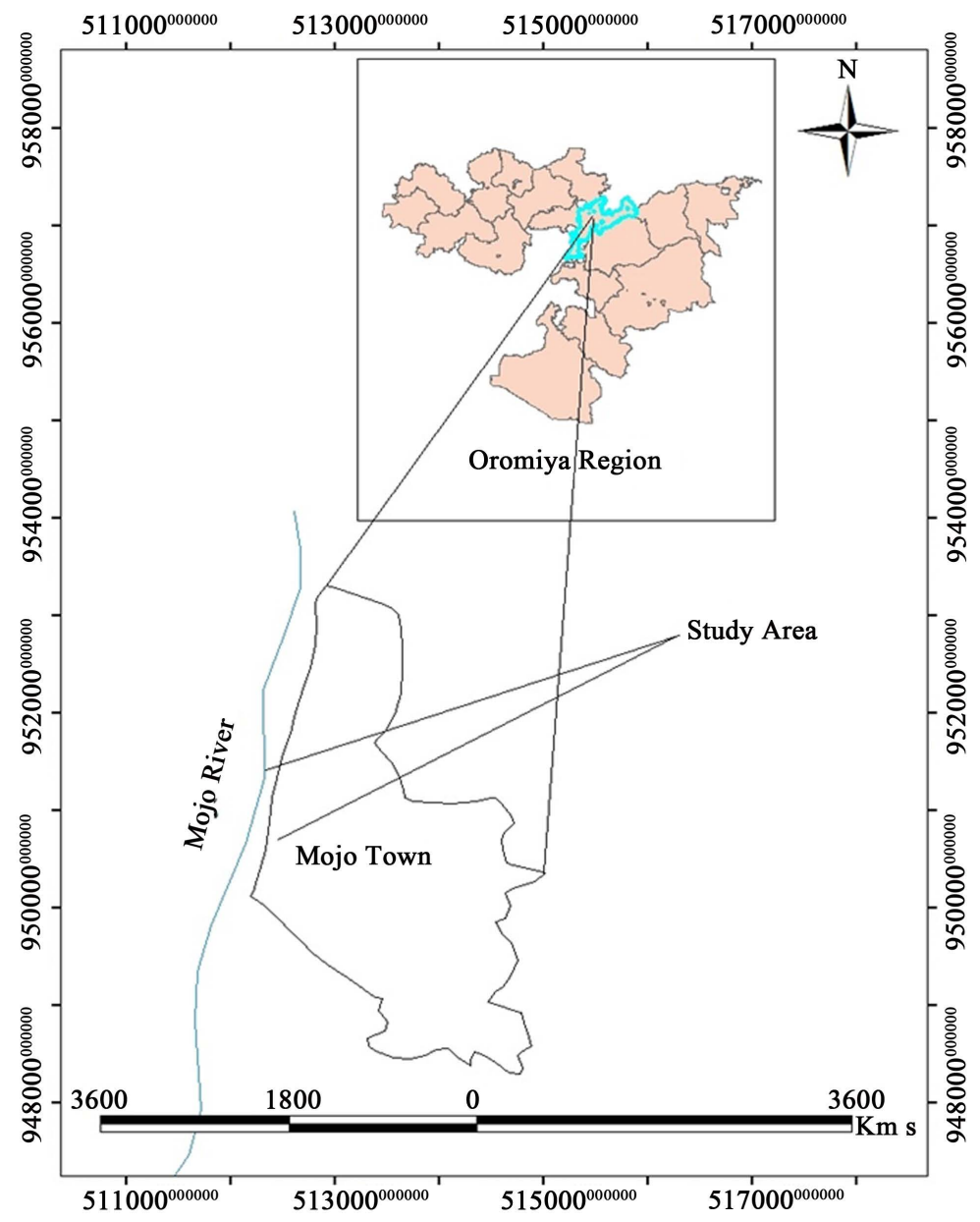

Figure 1. Map of study area.

respectively. The reference site was established from the upstream site of the river and is believed free of the Modjo tannery effluent. The samples were collected from the sites using a sampler which allows sampling from discrete depth and the sample was transferred into the storage bottle without agitation or aeration. All samples were collected in dry season in between January and February. Prior to sampling, the polyethylene bottle was cleaned with nitric acid and then washed and rinsed with distilled water. Finally both effluent and water samples were stored in icebox and transported to laboratory for analysis.

\subsection{Physicochemical Analysis}

The physicochemical parameters include $\mathrm{pH}$, temperature, BOD5, COD, ammonia-nitrogen $\left(\mathrm{NH}_{3}-\mathrm{N}\right)$, total nitrogen, total phosphorous, TDS, conductivity, TSS, chlorides and sulphides. These parameters were selected because they are considered to be deleterious on the receiving environment and they were included in the discharge limit. Temperature, $\mathrm{pH}$, conductivity and TDS were measured in situ using combined $\mathrm{pH} / \mathrm{T}^{\circ} / \mathrm{TDS}$ and conductivity meter. In the laboratory, BOD5 and COD were measured according to standard methods [15]. Total nitrogen, total phosphorous, chloride, and sulphide, were determined with Hach nutrient analysis kits and a Hach spectrophotometer (DR010 Hach Co., Loveland, Colorado, USA). Total suspended solids were determined gravimetrically.

Statistical Analysis: For the present study, the significance of variation within sample and between samples has been studied using one-way analysis of variance (ANOVA) for effluent (wastewater) and river water samples. The least significant difference (LSD) method was applied to test the mean differences at the $5 \%$ level of significance. All statistical data analysis was carried out using stastical package for social studies (SPSS) software version 16.0. 


\section{Results and Discussion}

The results of each physicochemical parameter of the tannery wastewater and river water samples have presented in the following Table 1 and Table 2 respectively.

Table 1. Average concentration (mean $\pm \mathrm{SD}, \mathrm{n}=3$ ) values of physicochemical parameters of tannery wastewater samples.

\begin{tabular}{|c|c|c|c|c|c|}
\hline \multirow{2}{*}{ Physicochemical parameters } & \multicolumn{3}{|c|}{ Sampling sites along the wastewater channel } & \multicolumn{2}{|c|}{ Discharge limit values } \\
\hline & E1 & E2 & E3 & FEPA & EEPA \\
\hline Temperature $\left({ }^{\circ} \mathrm{C}\right)$ & $26.97 \pm 0.06$ & $26.00 \pm 0.01$ & $24.93 \pm 0.06$ & $<40$ & 40 \\
\hline $\mathrm{pH}$ & $9.33 \pm 0.06$ & $8.89 \pm 0.01$ & $8.33 \pm 0.01$ & $6-9$ & $6-9$ \\
\hline $\mathrm{EC}\left(\mu \mathrm{S} \cdot \mathrm{cm}^{-1}\right)$ & $15670.00 \pm 20$ & $14830.00 \pm 10$ & $14496.67 \pm 40.41$ & 2500 & - \\
\hline $\operatorname{TDS}\left(\mathrm{mg} \cdot \mathrm{L}^{-1}\right)$ & $9370.00 \pm 10$ & $8890.00 \pm 8.1$ & $8723.33 \pm 5.77$ & 2000 & - \\
\hline $\mathrm{TSS}\left(\mathrm{mg} \cdot \mathrm{L}^{-1}\right)$ & $4979.33 \pm 26.86$ & $3540.00 \pm 20$ & $2647.67 \pm 7.50$ & 30 & 50 \\
\hline Chloride $\left(\mathrm{mg} \cdot \mathrm{L}^{-1}\right)$ & $6111.67 \pm 73.2$ & $5615.77 \pm 24.8$ & $5555.78 \pm 23.74$ & 600 & 1000 \\
\hline BOD5 $\left(\mathrm{mg} \cdot \mathrm{L}^{-1}\right)$ & $960.34 \pm 33.24$ & $852.00 \pm 29.21$ & $842.00 \pm 27.5$ & 50 & 200 \\
\hline $\operatorname{COD}\left(\mathrm{mg} \cdot \mathrm{L}^{-1}\right)$ & $2011.00 \pm 45.67$ & $2000.45 \pm 43.5$ & $1950.75 \pm 39.2$ & 500 & 500 \\
\hline Total ammonia (as N) $\left(\mathrm{mg} \cdot \mathrm{L}^{-1}\right)$ & $520.44 \pm 29$ & $430.34 \pm 25.44$ & $401.23 \pm 23.5$ & & 30 \\
\hline Total nitrogen (as N) $\left(\mathrm{mg} \cdot \mathrm{L}^{-1}\right)$ & $720.46 \pm 33.5$ & $691.11 \pm 31.44$ & $665.43 \pm 28.5$ & & 60 \\
\hline Total phosphorus (as $\mathrm{P})\left(\mathrm{mg} \cdot \mathrm{L}^{-1}\right)$ & $30.12 \pm 3.11$ & $24.33 \pm 2.23$ & $19.55 \pm 1.55$ & & 10 \\
\hline Sulphide (as S) $\left(\mathrm{mg} \cdot \mathrm{L}^{-1}\right)$ & $35.56 \pm 4.55$ & $29.39 \pm 3.45$ & $21.05 \pm 2.7$ & & 0.1 \\
\hline
\end{tabular}

$\mathrm{E} 1$ = the point of immediate discharge of mixed tannery effluents, E2 = the point about $400 \mathrm{~m}$ from E1 and E3 = the point about $800 \mathrm{~m}$ away from E1 or $400 \mathrm{~m}$ from E2.

Table 2. Average concentration (mean $\pm \mathrm{SD}, \mathrm{n}=3$ ) values of physicochemical parameters of river water samples.

\begin{tabular}{|c|c|c|c|}
\hline \multirow{3}{*}{ Physicochemical parameters } & \multicolumn{3}{|c|}{ Sampling sites } \\
\hline & \multicolumn{2}{|c|}{ Downstream sites } & \multirow{2}{*}{$\begin{array}{l}\text { Upstream site } \\
\text { Wup (control) }\end{array}$} \\
\hline & W1 & W2 & \\
\hline Temperature $\left({ }^{\circ} \mathrm{C}\right)$ & $21.70 \pm 0.06$ & $21.20 \pm 0.01$ & $20.47 \pm 0.06$ \\
\hline $\mathrm{pH}$ & $8.15 \pm 0.01$ & $7.69 \pm 0.03$ & $7.94 \pm 0.04$ \\
\hline $\mathrm{EC}\left(\mu \mathrm{Scm}^{-1}\right)$ & $5570.00 \pm 10$ & $4753.33 \pm 5.77$ & $340.33 \pm 0.58$ \\
\hline TDS $\left(\mathrm{mg} \cdot \mathrm{L}^{-1}\right)$ & $3338.33 \pm 2.89$ & $2861.67 \pm 2.89$ & $204.67 \pm 0.58$ \\
\hline TSS $\left(\mathrm{mg} \cdot \mathrm{L}^{-1}\right)$ & $1397.00 \pm 5.58$ & $818.67 \pm 4.51$ & $380.67 \pm 3.03$ \\
\hline Chloride $\left(\mathrm{mg} \cdot \mathrm{L}^{-1}\right)$ & $1766.91 \pm 48.19$ & $1239.40 \pm 29.43$ & $171.50 \pm 17.62$ \\
\hline BOD5 $\left(\mathrm{mg} \cdot \mathrm{L}^{-1}\right)$ & $73.40 \pm 6.46$ & $55.00 \pm 4.44$ & $11.40 \pm 1.23$ \\
\hline $\mathrm{COD} \mathrm{mg} \cdot \mathrm{L}^{-1}$ & $206.00 \pm 33.4$ & $164.00 \pm 25.4$ & $27.40 \pm 10.3$ \\
\hline Total ammonia (as N) $\left(\mathrm{mg} \cdot \mathrm{L}^{-1}\right)$ & $99.34 \pm 12.11$ & $55.54 \pm 7.56$ & $4.50 \pm 1.01$ \\
\hline Total nitrogen (as N) $\left(\mathrm{mg} \cdot \mathrm{L}^{-1}\right)$ & $143.50 \pm 17.5$ & $78.13 \pm 8.5$ & $9.34 \pm 2.11$ \\
\hline Total phosphorus (as $\mathrm{P})\left(\mathrm{mg} \cdot \mathrm{L}^{-1}\right)$ & $10.34 \pm 1.55$ & $5.30 \pm 0.76$ & $2.10 \pm 0.45$ \\
\hline Sulphide (as S) $\left(\mathrm{mg} \cdot \mathrm{L}^{-1}\right)$ & $14.55 \pm 1.23$ & $5.00 \pm 0.55$ & $0.11 \pm 0.05$ \\
\hline
\end{tabular}

$\mathrm{W} 1$ = downstream site of the river at about $500 \mathrm{~m}$ away from the point where the tannery wastewater joins the river, W2 = downstream site of the river at about $500 \mathrm{~m}$ from W1 and Wup = upstream site of the river at about $200 \mathrm{~m}$ from the confluence point where the tannery wastewater joins the river. 
Temperature: The temperature of water and wastewater is one of the most important characteristics that determines, to a considerable extent, the trends and tendencies of changes in the river water quality. Increased water temperature decreases the solubility of dissolved oxygen and water temperatures above $27^{\circ} \mathrm{C}$ are "unsuitable" for public use. At above $32^{\circ} \mathrm{C}$ it would be considered "unfit" for public use [16]. Toxic chemicals made more soluble by higher temperature may present an additional hazard to the organisms in the water [17]. Therefore, in the present study, temperature of the wastewater (effluent) along the wastewater channel varies from $26.97^{\circ} \mathrm{C}$ to $24.93^{\circ} \mathrm{C}$ (Table 1), and these values were below the discharge limit values set by EEPA $\left(40^{\circ} \mathrm{C}\right)$ and FEPA $\left(<40^{\circ} \mathrm{C}\right)$ for industrial effluents to be discharged into water body. Analysis of variance (ANOVA) indicated that variation among the sampling points were statistically significant $(p<0.05)$. Temperatures of the river water sample also vary from 20.47 upstream to about $21.70^{\circ} \mathrm{C}$ downstream site of the river. The temperature of the downstream site of the river is a little bit higher than the upstream site which is used as control but not statistically significant.

pH: Determination of $\mathrm{pH}$ is very important because it influences the other physicochemical parameters and the availability of metal ion in the water and wastewater. The results of this study showed that the levels of $\mathrm{pH}$ ranged from 9.33 to 8.33 and 8.15 and 7.69 for wastewater (effluent) and river water samples, respectively. Of the sampling points of effluent, point E1 show higher $\mathrm{pH}$ value than point E2 and E3 which was basic. These high values might be as a result of lime, soda ash, sodium sulphide and caustic soda used in the hides and skins processing. The $\mathrm{pH}$ value at E1 (9.33) was above the standard value for industrial effluents discharged to water bodies set by FEPA and EEPA which is 6 - 9. However, the average $\mathrm{pH}$ value which is 8.85 along the wastewater channel was within the discharge limit. Similarly, the level of $\mathrm{pH}$ in the upstream and downstream site of the river varied between 8.15 and 7.69. The mean $\mathrm{pH}$ values recorded in the downstream site of the river was comparable to the values obtained from the upstream site which is used as control.

Electrical Conductivity (EC): The EC is a valuable measure of the amount of ions dissolved in wastewater and water. In this study, the value of EC along the wastewater channel ranged from 15,670.00 to 14,496.67 $\mu \mathrm{Scm}^{-1}$ (Table 1). The obtained values in all sampling sites were higher than the FEPA standard value (2500 $\mu \mathrm{S} \cdot \mathrm{cm}^{-1}$ ) of tannery effluent to be discharged into water body. These high values could be attributed to different dissolved salts used in the tannery industry. The EC of river water sample ranged from $5570.00 \mu \mathrm{S} \cdot \mathrm{cm}^{-1}$ to $340.33 \mu \mathrm{S} \cdot \mathrm{cm}^{-1}$ (Table 2). The EC values decreased from W1 to W2 in the downstream site of the river and this might be due to dilution. Analysis of variance (ANOVA) also indicated that variation among the sampling points were statistically significant $(p<0.05)$. In addition to this the EC in the downstream site of the river were also much higher than the value obtained from the upstream site Wup ( $340.33 \mu \mathrm{S} \cdot \mathrm{cm}^{-1}$ ) which is expected to be less polluted and free of the Modjo tannery wastewater. This result shows that the downstream site of the river is polluted due to the direct discharge of the tannery effluent. The high values of EC in the downstream site of the river could be as a result of extreme soluble salts from the tannery effluent discharged into the river water body.

Total Suspended Solids (TSS): Regarding the value of TSS, the wastewater (effluent) and river water samples showed much presence of contaminants, as the values ranged from $4979.33 \mathrm{mg} \cdot \mathrm{L}^{-1}$ to $2647.67 \mathrm{mg} \cdot \mathrm{L}^{-1}$ along the wastewater channel and from $1397.00 \mathrm{mg} \cdot \mathrm{L}^{-1}$ to $380.67 \mathrm{mg} \cdot \mathrm{L}^{-1}$ in the river water samples. Conversely, TSS value is usually taken as an index of contamination potential of water. Literature classified wastewater TSS as follows, if TSS is less than $100 \mathrm{mg} \cdot \mathrm{L}^{-1}$ as weak, greater than $100 \mathrm{mg} \cdot \mathrm{L}^{-1}$ but less than $220 \mathrm{mg} \cdot \mathrm{L}^{-1}$ as medium and greater than $220 \mathrm{mg} \cdot \mathrm{L}^{-1}$ as strong wastewater [18]. The result of this study indicated that wastewater from the Modjo tannery could be classified as strong wastewater and should not be discharged in to the stream according to the standards. These values for TSS in the entire sampling points were higher than the discharge limits set by FEPA $\left(30 \mathrm{mg} \cdot \mathrm{L}^{-1}\right)$ and EEPA $\left(50 \mathrm{mg} \cdot \mathrm{L}^{-1}\right)$. These high TSS values observed in all the sampling points under studied might be possible due to the presence of fine leather particles, residues from various chemical discharges and reagents of the tannery. In the downstream site of the river the TSS values become decreased from point W1 to W2 (Table 2) and this decreased in concentration might be due dilution and adsorption by sediments and other organic matters present in the river water. Analysis of variance (ANOVA) also indicated that variation among the sampling points of both wastewater and river water were statistically significant $(p<0.05)$. The TSS value of the downstream site of the river was also higher as compared to the up-stream site of the river. This indicated that the downstream site of the river is polluted as the result of the tannery wastewater.

Total Dissolved Solids (TDS): TDS can also be taken as an indicator for the general water quality because it directly affects the aesthetic value of the water by increasing turbidity. In the present study, the concentration of TDS along the tannery wastewater channel ranged from $9370.00 \mathrm{mg} \cdot \mathrm{L}^{-1}$ to $8723.33 \mathrm{mg} \cdot \mathrm{L}^{-1}$ (Table 1 ). The val- 
ues of TDS in all sampling points were higher than the discharge limit of FEPA $\left(2000 \mathrm{mg} \cdot \mathrm{L}^{-1}\right)$ for effluents to be discharged into water body. The high values of TDS might be due to carbonates, bicarbonates, chlorides, sulphates, phosphates, nitrates, nitrogen, calcium, sodium, potassium and iron present in the waste water. Analysis of variance (ANOVA) also indicated that variation among the sampling points were statistically significant $(p<0.05)$. And this variation might be due to neutralization by the different chemicals released from the tannery as well as adsorption along the wastewater channel. TDS values of the River water sample also ranged from $3338.33 \mathrm{mg} \cdot \mathrm{L}^{-1}$ to $204.67 \mathrm{mg} \cdot \mathrm{L}^{-1}$. TDS levels recorded in the downstream site of the river were higher as compared to the upstream site which is used as control (Table 2) indicated that the tannery effluent is affected the river quality. Reference [19] also reported that high concentrations of TDS limit the suitability of water as a drinking source and irrigation supply.

Chloride: In this study, the results of chlorides along both wastewater (effluent) channel and river water sample sites varied from 6111.67 to $5555.97 \mathrm{mg} \cdot \mathrm{L}^{-1}$ and from 1766.92 to $171.50 \mathrm{mg} \cdot \mathrm{L}^{-1}$, respectively. According to the ANOVA, the concentrations $\mathrm{Cl}^{-}$at all sampling sites in both the wastewater and river water were significantly varied $(p<0.05)$. The chloride level recorded in the entire sampling points of the wastewater channel was higher than the permissible levels of chloride for safe effluent discharge into water bodies set by FEPA (600 $\left.\mathrm{mg} \cdot \mathrm{L}^{-1}\right)$ and EEPA $\left(1000 \mathrm{mg} \cdot \mathrm{L}^{-1}\right)$. The high concentrations of chloride in the effluent channel might be due to the fact that chlorides are introduced in to tannery effluents as sodium chloride usually on account of the large quantities of common salt used in hide and skin preservation or the pickling process as stated by [20]. The chloride contents in the downstream site of the river were also higher as compared to the upstream site (Wup) which serves as control. This indicated that the downstream site of the river is polluted as the result of direct discharge of tannery effluent. Reference [21] also stated that high chloride content in river may harm to growing plants this also limits the water for irrigation and drinking purpose.

BOD5 and COD: In the present study the levels of BOD5 and COD along the tannery wastewater channel ranged from 960.34 to $842.00 \mathrm{mg} \cdot \mathrm{L}^{-1}$ and 2011.00 to $1950.00 \mathrm{mg} \cdot \mathrm{L}^{-1}$ respectively (Table 1 ). All these values were above the discharge limit given by FEPA and EEPA (Table 1). These high levels of BOD5 and COD values observed in the effluent might be due to high amount of organic matter from various chemicals used during the processing of hides and skins. It has been reported that a significant part of chemicals used in the tanning process is not actually absorbed in the process and discharged into the environment [22], thereby increasing the levels of BOD5 in the effluent. The high BOD5 and COD contents of the effluent can affect the survival of gill breathing animals of the receiving water body and high COD value indicate toxic state of the wastewater along with the presence of biologically resistant organic substances. In the downstream site of the river W1 and W2, high levels of BOD5 and COD were recorded (Table 2). BOD5 and COD values at the upstream site (Wup) were significantly lower than the two downstream sites (W1 and W2). This indicated that the tannery wastewater is polluting the downstream site of the river.

Ammonia-N and Total Nitrogen: The concentrations of ammonia-N and total nitrogen along the tannery wastewater channel (drain) ranged from 520.44 to $401.23 \mathrm{mg} \cdot \mathrm{L}^{-1}$ and 720.46 to $665.43 \mathrm{mg} \cdot \mathrm{L}^{-1}$ respectively (Table 1). Their values differed significantly among sampling sites $(p<0.05)$. And all these values were above the discharge limit of EEPA which is 30 and $60 \mathrm{mg} \cdot \mathrm{L}^{-1}$ respectively. These high levels of ammonia-N and nitrogen might be attributed to several components in tannery effluent containing nitrogen as part of the chemical structure and the nitrogen contained in proteinaceous material of the skin [23]. The concentrations of ammonia- $\mathrm{N}$ and total nitrogen in the downstream site of the river were varied from 99.34 to $55.54 \mathrm{mg} \cdot \mathrm{L}^{-1}$ and 143.50 to 78.13 $\mathrm{mg} \cdot \mathrm{L}^{-1}$ respectively (Table 2). The concentrations both of ammonia- $\mathrm{N}$ and total nitrogen significantly varied among all sampling sites $(p<0.05)$. The levels of ammonia- $\mathrm{N}$ and total nitrogen in the downstream site of the river were above the values obtained from the upstream site of the river which is 4.50 and $9.34 \mathrm{mg} \cdot \mathrm{L}^{-1}$ respectively. Thus shows that the downstream site of the river is polluted due to the tannery wastewater discharged to it. High level of ammonia-N is toxic to aquatic organism and nitrogen may cause eutrophic condition.

Total Phosphorus and Sulphide: The levels of phosphorus and sulphide along the wastewater channel (drain) were ranged from 30.12 to $19.55 \mathrm{mg} \cdot \mathrm{L}^{-1}$ and 35.56 to $21.05 \mathrm{mg} \cdot \mathrm{L}^{-1}$ respectively (Table 1 ). The values of both phosphorus and sulphide at all sampling sites were higher than the discharge limit set by EEPA which is 10 and $0.1 \mathrm{mg} \cdot \mathrm{L}^{-1}$ respectively. The concentrations of phosphorus and sulphide in the downstream site of the river ranged from 10.34 to 5.30 and 14.55 to $5.00 \mathrm{mg} \cdot \mathrm{L}^{-1}$ respectively. And all these values were higher as compared to the values obtained from the upstream site (Wup) (control) which is believed free of the Modjo tannery effluent (Table 2). This indicated that the river is in increasing of these pollutants as the result of the direct discharge of tannery effluent. 


\section{Conclusion}

Even though tanning industries are important for the country's economy, their effluent is directly discharged into the nearby water body without treatment. The physicochemical parameters investigated in this study showed that almost all the effluent characteristics were above the provisional discharge limit set by the Environmental Protection Authority (EPA) indicating the poor treatment mechanism employed by the tannery. Most of the physicochemical parameters along the river water were also high and beyond the discharge limit. In addition to this the levels of all physicochemical parameters measured in the downstream site of the river were also high as compared to upstream site which was used as control. This indicated that the release of untreated wastewater from Modjo tannery influenced the quality of the receiving river water. Therefore, this will create a problem for downstream users as they use it for domestic, agricultural and recreational value.

\section{References}

[1] Ramasami, T., and Prasad, B. (1991) Environmental Aspects of Leather Processing. Journal of Indian Leather Technologists Association, 2, 43-71

[2] Tariq, S., Shaheen, N., Khalique, A. and Shah, M. (2010) Distribution, Correlation and Source Apportionment of Selected Metals in Tannery Effluents Related Soils and Ground Water a Case Study from Multan, Pakistan. Journal of Environmental Monitoring Assessment, 166, 303-312. http://dx.doi.org/10.1007/s10661-009-1003-9

[3] Petruzzelli, D., Passino, R. and Tiravanti, G. (1995) Ion Exchange Process for Chromium Removal and Recovery from Tannery Wastes. Journal of Industrial \& Engineering Chemistry Research, 34, 2612-2617. http://dx.doi.org/10.1021/ie00047a009

[4] Tariq, S., Shah, M., Shaheen, N., Khalique, A., Manzoor, S. and Jaffar, M. (2006) Multivariate Analysis of trace Metal Levels in Tannery Effluents in Relation to Soil and Water: A Case Study from Peshawar, Pakistan. Journal of Environmental Management, 79, 20-29. http://dx.doi.org/10.1016/j.jenvman.2005.05.009

[5] Ludvick, J. (2000) The Scope for Decreasing Pollution Load in Leather Processing. Regional Programme for Pollution Control in the Tanning Industry in South East Asia. UNIDO. US/RAS/92/120/11-51, 2-32.

[6] Teodorescu, M. and Gaidau, C. (2007) Possible Steps to Follow for Filling the Gap between Requirements and the Real Condition in Tanneries. Journal of Cleaner Production, 16, 622-631. http://dx.doi.org/10.1016/j.jclepro.2007.01.010

[7] World Bank (1998) Pollution Prevention and Abatement: Tanning and Leather Finishing. Draft Technical Background Document, Washington DC.

[8] Wiegant, W., Kalker, T., Sontakke,V. and Zwaag, R. (1999) Full Scale Experience with Tannery Water Management: An Integrated Approach. Water Science and Technology, 39, 169-176. http://dx.doi.org/10.1016/S0273-1223(99)00099-2

[9] ETPI (1998) Environmental Report of the Leather Sector. Draft Final Report, Environmental Technology Program for Industry, Karachi.

[10] Mondal, N., Saxena, V. and Singh, V. (2005) Impact of Pollution due to Tanneries on Groundwater Regime. Current Science, 88, 1988-1994.

[11] Weber-Scannell, P. and Duffy, I. (2007) Effects of Total Dissolved Solids on Aquatic Organisms: A Review of Literature and Recommendation for Salmonid Species. American Journal of Environmental Science, 3, 1-6. http://dx.doi.org/10.3844/ajessp.2007.1.6

[12] EEPA (2001) Situation Analysis; the Industrial Sector. ESID Project US/ETH/99/068/ETHIOPIA, EPA/UNIDO, Addis Ababa.

[13] Zinabu, G. and Zerihun, D. (2002) The Chemical Compostion of the Effluent from Awassa Textile Factory and Its Effects on Aquatic Biota. Ethiopian Journal of Science, 25, 263-274.

[14] Ethiopian Privatization Agency (2002) The Leather Industry. EPA [Online]. http://www.telecom.net.et/ epa/sectors/leather.html

[15] APHA (1998) Standard Methods for the Examination of Water and Wastewater. 20th Edition, APHA, Washington DC.

[16] Chapman, D. (1996) Water Quality Assessments: A Guide to the Use of Biota, Sediments and Water in Environmental Monitoring. 2nd Edition, Chapman and Hall Ltd., London, 651. http://dx.doi.org/10.4324/noe0419216001

[17] USEPA (1986) Quality Criteria for Water (“Gold Book”): Office of Water Regulations and Standards, EPA-440/586-001, USEPA, Washington DC.

[18] Haruna, A., Uzairu, A. and Harrison, G. (2009) Monitoring of Sewage Quality for Small-Scale Irrigation: Case Studies 
in Some Fadama Lands in Zaria City, Nigeria. Continental Journal of Applied Sciences, 4, 8-17.

[19] Awofolu, O., Mbolekwa, Z., Mtshemla, V. and Fatoki, O. (2005) Levels of Trace Metals in Water and Sediments of Tyume River and Its Effect on the Irrigated Farmland. Journal of Water Sanitation, 31, 87-94. http://dx.doi.org/10.4314/wsa.v31i1.5124

[20] UNIDO (2000) Pollutants in Tannery Effluents. Regional Program for Pollution Control in the Tanning Industry in South-East Asia. UNIDO, Vienna.

[21] Bartram, J. and Balance, R. (1996) Water Quality Monitoring: A Practical Guide to the Design and Implementation of Fresh Water Quality Studies and Monitoring Programmes. Chapman \& Hall, London, 400.

[22] UNIDO (1991) Leather Industry. Conference on Ecologically Sustainable Industrial Development. Case Study No. 3. ID/WG.516/10. UNIDO Secretariat, Copenhagen.

[23] Bosnic, M., Buljan, J. and Daniels, R. (2000) Pollutants in Tannery Effluents. Definitions and Environmental Impact, Limits for Discharge into Water Bodies and Sewers. UNIDO. Regional Programme for Pollution Control in the Tanning Industry in South-East Asia. US/RAS/92/120. 